\title{
Productivity and efficiency of cow herds submitted to two weaning ages
}

\author{
Ricardo Zambarda Vaz${ }^{1}$, José Fernando Piva Lobato², João Restle ${ }^{3}$
}

\footnotetext{
${ }^{1}$ Departamento de Zootecnia - Faculdade de Agronomia - UFRGS.

${ }^{2}$ Departamento de Zootecnia - Faculdade de Agronomia - UFRGS.

${ }^{3}$ Departamento de Zootecnia - Faculdade de Veterinária - UFG.
}

\begin{abstract}
It was aimed in this work to evaluate the productivity and efficiency of beef cows submitted to weaning of their calves at 76 days (early weaning) or at 148 days (weaning at conventional age) after calving during three consecutive years. It was evaluated pregnancy rate, birth and weaning, gain weight of the calves and cows at conventional weaning, weight at conventional weaning of calves and cows, production of weaned calves per cow and calf production index. Pregnancy rate in the herd submitted to early weaning $(86.34 \%)$ was higher than in the conventional weaning (55.5\%). Early weaning cows showed higher birth and weaning rates when compared to conventional weaning ( 83.6 and $83.6 \%$ vs. 47.5 and $44.5 \%$, respectively) besides a higher production of calves (183 vs. 114). Early weaning cows produced $60.5 \%$ more calves than the conventional weaning cows. Conventional weaning calves gained more weight from birth to weaning (97.9 vs. $83.4 \mathrm{~kg}$, respectively). Early weaning cows had more weight gain from calving to weaning (42.5 vs. $18.7 \mathrm{~kg}$, respectively), and regarded to calf production index, they were more efficient (efficiency of the herds). At the average of the three years, the early weaning of the calves allows higher calving rates and weaning to the cows, in addition to a higher index of calf kilogram index produced in relation to weaning at conventional age.
\end{abstract}

Key Words: conventional weaning, early weaning, index of calf production, weaning rate, weight gain

\section{Produtividade e eficiência de rebanhos de vacas submetidas a duas idades de desmame}

\begin{abstract}
RESUMO - A produtividade e a eficiência de vacas de corte submetidas ao desmame de seus bezerros aos 76 dias (desmame precoce) ou aos 148 dias (desmame à idade convencional) pós-parto foram medidas durante três anos consecutivos. Avaliaram-se as taxas de prenhez, natalidade e desmama, o ganho de peso de bezerros e de vacas do parto ao desmame convencional, o peso à desmama convencional de bezerros e vacas, a produção de bezerros desmamados por vaca e o índice de produção de bezerros. A taxa de prenhez no rebanho submetido ao desmame precoce $(86,4 \%)$ foi superior à do desmame convencional $(55,5 \%)$. Vacas do desmame precoce tiveram maiores taxas natalidade e de desmame em comparação às do desmame convencional (83,6 e $83,6 \%$ vs 47,5 e $44,5 \%$, respectivamente), além de maior produção de bezerros (183 vs. 114). As vacas do desmame precoce produziram $60,5 \%$ a mais de bezerros que as vacas do desmame convencional. Os bezerros de desmame convencional foram os que ganharam mais peso desde o nascimento até o desmame (97,9 vs $83,4 \mathrm{~kg}$, respectivamente). As vacas do desmame precoce tiveram maior ganho de peso do parto até o desmame (42,5 vs 18,7 kg, respectivamente) e foram mais eficientes quanto ao índice de produção de bezerros (eficiência dos rebanhos). Na média dos três anos, o desmame precoce dos bezerros permite às vacas maiores taxas de prenhez e de desmame, além de maior índice de quilos de bezerro produzido em relação ao desmame em idade convencional.
\end{abstract}

Palavras-chave: desmame convencional, desmame precoce, ganho de peso, índice de produção de bezerros, taxa de desmama

\section{Introduction}

Breeding herd reproductive efficiency significantly influences productivity indexes (Beretta et al., 2002). Traditional beef production systems, with low reproductive rates and late-finishing steers present low productivity (Pötter et al., 2000).
Productive efficiency of beef cattle in breeding herds is directly related to the reproductive performance of cows, and it is associated to maternal ability of the dam and potential weight gain of their calves (Restle et al., 1984; Ribeiro et al., 2001). The productivity of breeding systems may be increased by using of technological processes (Costa et al., 1981; Vieira et al., 2005), aiming at improving 
dam nutritional status and body condition throughout the year.

Nursing affects breeding herd performance (Simeone \& Lobato, 1996; Restle et al., 2001). There are evidences of the effect of calf suckling on calving interval (Freetly, 1999; Lobato et al., 2000), suggesting that anestrus during lactation, as a consequence of cow nutritional status and a possible endocrine suppression due to lactation as well as the mere presence of the calf, may cause estrus inhibition (Short et al., 1990).

The practice of early weaning in production systems aims at allowing cows to recover their body weight and body condition score after being submitted to feed restriction, such as the case of high stocking rates (Simeone \& Lobato, 1996; Fagundes et al., 2003), and to improve their reproductive efficiency (Moojen et al., 1994; Pascoal \& Vaz, 1997; Restle et al., 2001; Fagundes et al., 2003; Almeida \& Lobato, 2004).

Several production efficiency measurements are proposed in literature (Restle et al., 1984; Euclides filho et al., 1995; Ribeiro et al., 2001). Reproductive performance data must be added to these production efficiency indexes to allow a better understanding on herd productivity (Euclides filho et al., 1984; Barcellos et al., 1996; Lobato et al., 2000). In addition, environment variables and pre- and/or postcalving feeding management of the cows may influence beef cow performance (Lobato et al., 1998ab; Pötter \& Lobato, 2004).

The objective of the present study was to evaluate the influence of early weaning on the production and reproductive performance and on production efficiency of two beef cow herds.

\section{Material and Methods}

The experiment was carried out on Granja Itú, located in Itaqui, RS, Brazil, latitude $29^{\circ} 12^{\prime}$ south and longitude $55^{\circ} 36^{\prime}$ west. The relief consists of hills and valleys, with deep, naturally-acid soils with intermediate surface texture. The soil is classified as red podzolic latosol (EMBRAPA, 1999). The climate is subtropical, according to Köppen's classification (Moreno, 1961).

In this experiment, 141 Braford cows with first calving at 36 months of age, were distributed in two groups. In one group, calves were weaned at 76 days of age (early weaning), and in the other group, calves were weaned at 148 days of age (conventional weaning).

The number of replicates varied according to the observation year, as it follows: 71, 63, and 53 cows in the early-weaning group, and 70, 28, and 20 in the conventional- weaning group. Early-weaning cows calved 104 females and 81 males, whereas conventional-weaning cows calved 57 females and 81 males during the springs of 2004, 2005 and 2006 , from September $7^{\text {th }} 2004$ to October $15^{\text {th }} 2005$, from October $5^{\text {th }}$ to December $1^{\text {st }} 2005$, and from October $10^{\text {th }}$ 2006 to November $25^{\text {th }} 2006$, respectively. These calves were calved by primiparous cows in the first year, and by the same cows in the following years. As the study started with primiparous cows at three years of age (2004), and with the same cows calving at 4 (2005) and 5 (2006) years of age, these effects are completely confounded and they were considered as the joint effect of calf birth year and cow age. Non-pregnant cows were culled every year.

Cows whose calves were submitted to the two weaning ages were managed as a single group; the only difference was the calf weaning age. Between the first (September/ 2004) and the second calving (September/2005) cows were maintained on natural pastures at a stocking rate of $320 \mathrm{~kg}$ live weight/ha, as well as during periods when they were not lactating. Between the second calving until conventional weaning of the second generation of calves $\left(10^{\text {th }} / 12 / 2005\right.$ to $2^{\text {nd }} / 2 / 2006$ ), cows were managed on Brachiaria pasture (Brachiaria brizantha, cv Marandu). After weaning, they returned to natural pastures until the beginning of the calving season (September/2006), when they were again grazed on another Brachiaria (Brachiaria humidicola (Rendle) schweick) pasture until the date of conventional weaning $\left(15^{\text {th }} / 12 / 2006\right.$ to $\left.5^{\text {th }} / 02 / 2007\right)$.

Early weaning occurred from December to February and it was performed when calves reached 60 to 70 days of age, except for those born in 2004, which were weaned together in a single lot on December, $26^{\text {th }} 2004$ at an average age of 91 days, resulting in an average of 76 days for the three years of observation. Conventional weaning was performed on a single day in the beginning of March $\left(5^{\text {th }} / 03 / 2005,3^{\text {rd }} / 3 / 2006\right.$, and $\left.6^{\text {th }} / 3 / 2007\right)$, aiming at allowing the cows to recover their weight and to accumulate body reserves before winter (Lobato, 2003).

The following reproductive efficiency parameters were evaluated during three years (from calving in 2004 to pregnancy diagnosis in the 2006/2007 breeding season): pregnancy rate, birth rate, and weaning rate relative to the number of cows mated in the previous year. In addition, mortality rate took into account deaths that occurred from pregnancy diagnosis to birth and from birth to weaning.

Herd productivity and breeding-cow efficiency considered total cow and calf weight gains $(\mathrm{kg})$ from calving up to conventional weaning. Calf production efficiency was measured as calf production rate adjusted to pregnancy rate in kilograms of weaned calf per cow (weight of calves 
submitted to conventional weaning * pregnancy rate/100) and in $\mathrm{kg}$ of weaned calf per $100 \mathrm{~kg}$ cow metabolic weight at weaning ( $\mathrm{kg}$ calf weaned $\left./ 100 \mathrm{~kg} \mathrm{cow}{ }^{0.75}\right)$. The obtained reproductive efficiency, as well as cow productivity and efficiency values express the average of three years of observation due to the different number of replicated per year resulting from the culling of cows with negative pregnancy diagnosis.

Average pregnancy rates obtained in the breeding seasons of $2004 / 2005 ; 2005 / 2006$, and 2006/2007 were 91.6 , $83.9,82.0 \%$, and $41.2,72.0$, and $88.3 \%$, with averages of 86.3 and $55.5 \%$ (Vaz \& Lobato, 2010b) for cows submitted to early and conventional weaning, respectively.

Herd productivity and breeding-cow efficiency considered conventionally weaned calf weight per cow and weaned calf weight per $100 \mathrm{~kg}$ of cow live weight. These parameters were calculated according to the numbers of cows exposed to mating during the breeding seasons of $2004 / 2005$ and 2005/2006 and to the number of live calves at the time of conventional weaning in March, 2006 and March, 2007. Average cow weight at the beginning of the breeding season, obtained at the time bulls were placed with herd, was used.

A completely randomized experimental design in a $2 \times 2 \times 3$ factorial arrangement (two weaning ages $\times$ two calf sexes $\times$ three years of observation) was applied. Results were submitted to analysis of variance and to the $F$ test. The mathematical model used in the analyses was:

$$
\begin{gathered}
\mathrm{Y}_{\mathrm{ijkl}}=\mu+\mathrm{T}_{\mathrm{i}}+\mathrm{S}_{\mathrm{j}}+\left(\mathrm{T}^{*} \mathrm{~S}\right)_{\mathrm{ij}}+\mathrm{R}_{\mathrm{k}}\left(\mathrm{T}^{*} \mathrm{~S}\right)_{\mathrm{ij}}+\mathrm{A}_{1}+\left(\mathrm{T}^{*} \mathrm{~A}\right)_{\mathrm{il}}+ \\
(\mathrm{A} * \mathrm{~S})_{\mathrm{lj}}+\left(\mathrm{T}^{*} \mathrm{~S}^{*} \mathrm{~A}\right)_{\mathrm{ij} 1}+\Sigma_{\mathrm{ijk},}
\end{gathered}
$$

where: $Y_{i j k 1}=$ dependent variables; $\mu=$ mean of all observations; $T_{i}=$ effect of the $i^{\text {th }}$ weaning age, with $i=1$ (early weaning); 2 (conventional weaning); $\mathrm{S}_{\mathrm{j}}=$ effect of the $\mathrm{j}^{\text {th }}$ calf sex, with $\mathrm{j}=1$ (male); $2=\left(\right.$ female); $\mathrm{T}^{*} \mathrm{~S}_{\mathrm{ij}}$ = effect of the interaction of the $i^{\text {th }}$ age at weaning with $j^{\text {th }}$ calf sex; $R_{k}$ $\left(\mathrm{T}^{*} \mathrm{~S}\right)_{\mathrm{ij}}=$ effect of the $\mathrm{k}^{\text {th }}$ animal within the interaction of the $i^{\text {th }}$ age at weaning with $j^{\text {th }}$ calf sex; $A_{1}=$ effect of $1^{\text {th }}$ year and cow age set; $T^{*} A_{i l}=$ effect of the interaction of $i^{\text {th }}$ age at weaning $\times$ effect $1^{\text {th }}$ year and cow age set; $T^{*} \mathrm{~S} * \mathrm{~A}$ ijl $=$ effect of the interaction of $i^{\text {th }}$ age at weaning $\times j^{\text {th }}$ calf sex $\times 1^{\text {th }}$ year and cow age set; $\Sigma_{i j k l}=$ residual error.

As the interactions $(T * S)_{i j} ;(A * S)_{1 j} ;(T * S * A)_{i j 1}$ were not significant, they were removed from the final statistical model. Analyses were carried out using the GLM procedures of SAS statistical package SAS, version 6.08 (SAS, 1997), at $5 \%$ significance level. Means were compared by the t-test. Pregnancy rate at different weaning ages was analyzed by the Chi-Square test at 5\% significance level.

\section{Results and Discussion}

From September 2004 to March 2007, it was evaluated the reproductive and productive performance of 141 cows in the beginning of the experiment and from those that got pregnant along three years of observation, totaling 305 replicates. As cows were initially distributed at first calving, there are no records of birth rates from the first breeding season (Table 1), and only weaning rates, considering the initial number of first-calf cows.

When observation years were compared, significant differences between rearing systems only during the first year, when cows were primiparous (Table1), were observed. Costa et al. (1981) and Restle et al. (2001) also found that primiparous cows were more affected by nursing on subsequent reproductive performance.

The obtained average birth and weaning rates of 68.5 and $66.8 \%$, respectively, do not support economically efficient beef production. Beretta et al. (2002) evaluated the physical productivity and the biological efficiency of beefcattle rearing systems and observed increasing birth rates of $73.4 \%, 80.4 \%$, and $84.4 \%$ as the age of the cows at first calving increased from 24,36 , and 48 months, respectively. Those authors concluded that this increase in birth rate determined the higher productivity of breeding-to fattening or traditional beef production systems.

Birth rates and weaning rates of breeding cows in both management systems were, in average, 83.8 and $83.6 \%$, and 47.5 and $44.4 \%$ for cows whose calves were submitted to

\begin{tabular}{|c|c|c|c|c|c|c|}
\hline \multirow[b]{2}{*}{ Breeding season } & \multicolumn{3}{|c|}{ Early weaning } & \multicolumn{3}{|c|}{ Conventional weaning } \\
\hline & $2004 / 2005$ & $2005 / 2006$ & $2006 / 2007$ & $2004 / 2005$ & $2005 / 2006$ & $2006 / 2007$ \\
\hline Exposed cows, $\mathrm{n}$ & 71 & 65 & 53 & 70 & 29 & 20 \\
\hline Pregnancy rate, $\%$ & $91.6 \mathrm{~A}$ & 83.9 & 82.0 & $41.2 \mathrm{~B}$ & 72.0 & 88.3 \\
\hline Birth rate, $\%$ & - & $88.7 \mathrm{~A}$ & 78.5 & - & $40.0 \mathrm{~B}$ & 65.5 \\
\hline Weaning rate, $\%$ & 98.6 & $88.7 \mathrm{~A}$ & 76.9 & 100.0 & $37.1 \mathrm{~B}$ & 62.1 \\
\hline Mortality pregnancy diagnosis-calving, $\mathrm{n}$ & - & 2 & 2 & - & 1 & 1 \\
\hline Mortality calving-conventional weaning, $\mathrm{n}$ & 1 & 0 & 1 & 0 & 2 & 1 \\
\hline
\end{tabular}

Table1 - Reproductive performance and mortality of cows during the evaluated years

A, B Mean in the same row followed by different letters are different between weaning ages during the same year by the Chi-Square test.

Weaning age considering the date of conventional weaning.

Birth and weaning rates calculated on the total number of cows mated in the previous breeding season. 
early or conventional weaning, respectively, relative to all cows exposed to bulls. Considering only those cows maintained in the herd after open cows were removed from the analysis, birth and weaning rates were 96.5 and $95.7 \%$, and 95.7 and $90.0 \%$ for cows submitted to early and conventional weaning, respectively.

Vieira et al. (2005) evaluating cows of different ages in a Nelore herd in the central region of Brazil for four consecutive years, observed average birth and weaning rates of 81.7 and $77.2 \%$, when all cows exposed to bulls were considered, and higher rates, of 93.0 and $87.0 \%$, when open cows were not taken into account.

When weanings are separately evaluated, a considerable advantage of early weaning is observed in term of production indexes, which are very close to those considered optimal. Several studies have shown that early weaning promotes higher pregnancy, birth, and weaning rates when different weaning ages are compared (Simeone \& Lobato, 1996; Lobato et al., 2000; Restle et al., 2001; Fagundes et al., 2003).

When conventional weaning were individually analyzed, birth and weaning rates increased, probably because cows aged and were no longer primiparous cows (Vieira et al., 2005) thereby, had lower nutritional requirements (Freetly, 1999; Restle et al., 2001). Moreover, post-calving cows were offered better feeding conditions at the end of the second breeding season, when they were managed on Brachiaria brizanta, with $2,450 \mathrm{~kg} / \mathrm{ha}$ available dry matter, contrary to the first year, when they grazed on natural pastures with only $1,640 \mathrm{~kg} / \mathrm{ha}$ availability due to the high stocking rate of $320 \mathrm{~kg} / \mathrm{ha} /$ year. Excessive stocking rates impair beef cattle reproduction (Simeone \& Lobato, 1996; Fagundes et al., 2003). It must also be noted that, as open cows were culled at pregnancy diagnosis, cows whose genetics are better adapted to the environment remain in the herd (Vaz \& Lobato, 2010b).

Calf mortality rates ranged from 3 to $5 \%$ between pregnancy diagnosis and calving and between calving and conventional weaning age. Rovira (1974) reported 8\% mortality between pregnancy diagnosis and conventional weaning age. Corrêa et al. (2000), when evaluating the reproductive performance of cows with different genotypes, verified higher calf mortality as compared to the present study. Those authors concluded that, as primiparous cows are more sensitive, more care is required to prevent losses that influence the productive and economic performance of the herd.

When weaning ages were compared, no differences in mortality rates $(\mathrm{P}>0.05)$ were observed, even though there were differences of $100 \%$ in absolute numbers. However, due to the lower number of calves submitted to conventional weaning, different number of cows in each weaning age group in the same year, and the higher number of cows in the early weaning group due to their higher pregnancy rates, no statistical differences on calf mortality were detected.

During the three years of observation, $58.8,28.0$, and $11.7 \%$, and $8.4,16.1$ and $18 \%$ cows of the conventional weaning and early weaning groups, respectively, were culled. This resulted in $70.4 \%$ and $25.4 \%$ total culling of cows in the conventional and early weaning groups, respectively, considering the initial number of animals. It must be noted that both cow groups were managed as a single group, and that stocking rate adjustments were made when open cows were culled to maintain a stocking rate of $320 \mathrm{~kg}$ live weight/ha.

Keeping open cows in commercial herds results in lower productivity in calving-to-fattening systems (Pötter et al., 2000; Beretta etal., 2002). Had culling continued in the observed herd, in two or three years, the number of animals would have matched the stocking rate, with consequent higher forage availability and better reproductive responses (Simeone \& Lobato, 1996; Fagundes et al., 2003). In commercial production systems, as the one evaluated in the present study, such procedure may be used as an alternative; however, it is better to adjust stocking rates before emergence of "problems".

Another factor that must be considered when evaluating beef-cattle system profitability is adding value to market animals. Culled cows are often sold when they are thin and with low body condition score, obtaining lower prices as compared to culled cows and heifers with excellent body condition score (Vaz et al., 2000). These thin cows reduce herd profitability (Pötter et al., 2000; Beretta et al., 2002).

The productive performance of breeding herds may be improved by the use of improved pastures (Costa et al., 1981; Lobato et al., 1998ab; Lobato et al., 2000), lower stocking rates, and consequently higher forage availability of natural pastures (Simeone \& Lobato, 1996; Fagundes et al., 2003; Pötter \& Lobato, 2004) as well as by the use of early weaning (Simeone \& Lobato, 1996; Restle et al., 2001; Almeida etal., 2002; Fagundes et al., 2003; Lobato et al., 2007).

During the three years of observation, the practice of early weaning produced more calves $(\mathrm{P}<0.05 ; 183$ vs. 114 calves). The 71 and 70 cows in the beginning of the observation produced during the three years, in average, 61.3 and 38.0 early weaned and conventionally weaned calves per year, respectively (Table 2). Although many studies have not followed up subsequent calving of cows submitted to early weaning, the results consistently show 
that the pregnancy rates of these cows were higher than those submitted to conventional weaning (Lobato \& Barcellos, 1992; Moojen et al., 1994; Lobato et al., 2000; Restle et al., 2001; Almeida et al., 2002; Fagundes et al., 2003).

These means indicate that each cow managed under the early weaning regime produced 2.6 calves in three years, whereas those maintained under conventional weaning produced 1.6 calves during the same period. According to these data, breeding systems with weaning age of 148 days require two cows to produce one calf/year, making these systems expensive and inefficient since these productivity levels is not sufficient to cover fixed costs, such as land, labor, and input costs used by cows that did not conceive (Pötter et al., 2000; Beretta et al., 2001).

Although the introduction of the practice of early weaning in a herd requires financial and labor investments, this expense must be evaluated in the context of the production system, and not merely considering that parameter. According to Vaz et al. (2000), economic assessments usually do not analyze the effect of technology on beef cattle production systems as a whole, rather using a simplistic and limited analysis that does not take into consideration the indirect benefits for the entire system.

At the time of conventional weaning, calf weight was similar between weaning-age groups (Table 3 ). However, weight gain from birth to weaning was higher in calves weaned at 148 days of age $(\mathrm{P}<0.05)$ as compared to those weaned at 76 days of age, with weight gains of 97.9 and $83.4 \mathrm{~kg}$, respectively. This is explained by the better feeding conditions of calves weaned later than those submitted to early weaning, as the latter suffered the stress of weaning during the evaluation period (Restle et al., 2001), being fed feedstuffs to which their digestive tract was not yet completely adapted (Pascoal \& Vaz, 1997).

Lower weaning weight of early weaned calves at the time of conventional weaning were reported by Restle et al., 1999, Almeida \& Lobato, 2004; Lobato et al., 2007. However, the evaluation of the production system or the use of different techniques within a system have to regard other

Table 2 - Calf production in production systems using early weaning or conventional weaning

\begin{tabular}{lcc}
\hline Parameters & $\begin{array}{c}\text { Early } \\
\text { weaning }\end{array}$ & $\begin{array}{c}\text { Conventional } \\
\text { weaning }\end{array}$ \\
\hline Initially exposed cows, n & 71 & 70 \\
Calves at conventional weaning, n & $183 \mathrm{~A}$ & $114 \mathrm{~B}$ \\
Calves/cow initial, n & $2.6 \mathrm{~A}$ & $1.6 \mathrm{~B}$ \\
Calf in each system/year, n & $61.3 \mathrm{~A}$ & $38.0 \mathrm{~B}$ \\
\hline
\end{tabular}

A, B Means followed by capital letters in the same row are different $(\mathrm{P}<0.05)$ by Chi-Square test.

Production is related to the total initial number of cows during the three years of observation. benefits promoted by these techniques. For instance, cow weight gain $(\mathrm{kg})$ between calving and conventional weaning time (Table 3 ) was $172 \%(\mathrm{P}<0.05)$ higher in cows in the early weaning group as compared to those in the conventional weaning group (42.5 and $18.7 \mathrm{~kg}$, respectively). This difference in weight gain occurred in the period immediately after early weaning, when cows stop nursing, redirecting the consumed nutrients used for milk production to weight gain (Simeone \& Lobato, 1996; Almeida et al., 2002; Vaz \& Lobato, 2010b).

The weight gain of the cow-calf set between calving and time of conventional weaning was $126.0 \mathrm{vs} .116 .6 \mathrm{~kg}$ in the early weaning and conventional weaning systems, respectively. As calf development is not influenced by the use of early weaning (Restle et al., 1999; Lobato et al., 2007; Vaz \& Lobato 2010a), the higher weight gain results in higher pregnancy rates, reduced number of thin cows and risks during the winter, and higher accumulation of body reserves, which are reflected in higher milk production during the following lactation, and consequent higher calf weight gain. In cows with their last calves, this higher weight gain allows marketing fatter cows at a lower production cost (Pascoal \& Vaz, 1997).

In studies on herd productive efficiency, herds are submitted to the same management conditions (Barcellos et al., 1996; Ribeiro et al., 2001; Vieira et al., 2005). Most authors state that the ratio between calf weight and cow weight within a same production cycle is adequate to measure efficiency at individual or herd level (Barcellos et al., 1996; Ribeiro et al., 2001).

Table 3 - Reproductive performance, cow and calf weight gains from birth to conventional weaning time, and herd productivity and efficiency according to weaning system

\begin{tabular}{|c|c|c|}
\hline Parameters & $\begin{array}{c}\text { Early } \\
\text { weaning }\end{array}$ & $\begin{array}{c}\text { Conventional } \\
\text { weaning }\end{array}$ \\
\hline Pregnancy rate, \% & $86.3 \mathrm{~A}$ & $55.5 \mathrm{~B}$ \\
\hline Calf weight at 148 days $(\mathrm{kg})$ & 117.6 & 122.8 \\
\hline $\begin{array}{l}\text { Calf weight gain from birth } \\
\text { to } 148 \text { days }(\mathrm{kg})\end{array}$ & $83.4 \mathrm{~b}$ & $97.9 \mathrm{a}$ \\
\hline Cow weight gain from & & \\
\hline calving to 148 days $(\mathrm{kg})$ & $42.5 \mathrm{a}$ & $18.7 \mathrm{~b}$ \\
\hline $\mathrm{kg}$ weaned calf/cow weight $0.75, \mathrm{~kg}^{1}$ & $126.6 \mathrm{~b}$ & $149.1 \mathrm{a}$ \\
\hline $\mathrm{kg}$ weaned calf/cow weight $0.75, \mathrm{~kg}^{2}$ & $109.5 \mathrm{a}$ & $99.2 b$ \\
\hline Calf production index, $\mathrm{kg} / \mathrm{cow}^{3}$ & $102.3 \mathrm{a}$ & $59.1 \mathrm{~b}$ \\
\hline Herd productivity, $\mathrm{kg}$ calf/cow & $92.7 \mathrm{a}$ & $58.6 \mathrm{~b}$ \\
\hline Herd efficiency, $\mathrm{kg}$ calf $/ 100 \mathrm{~kg}$ cow & $27.9 \mathrm{a}$ & $16.5 \mathrm{~b}$ \\
\hline
\end{tabular}

A, B - Means followed by capital letters in the same column are different $(\mathrm{P}<0.05)$ by Chi-Square test.

a, $\mathrm{b}$ - Means followed by small letters in the same row are different $(\mathrm{P}<0.05)$ by F test.

${ }^{1}$ Calf weight at conventional weaning/cow metabolic weight at conventional weaning $* 100$.

${ }^{2}$ Calf weight at conventional weaning adjusted to pregnancy rate/cow metabolic weight at conventional weaning $* 100$.

${ }^{3}$ Calf weight at conventional weaning $\times$ pregnancy rate $/ 100=\mathrm{kg}$ weaned calf/ cow maintained in the herd. 
Although cows submitted to the different weaning ages were managed as a single group in the present experiment, the fact that they were nursing or not for a period of time affected their development. In the present study, calf managed was also changed, with the earlyweaned group presenting lower development as compared to calves submitted to conventional weaning (Restle et al., 1999; Pötter et al., 2004; Lobato et al., 2007).

Productivity and efficiency are forms to express the results of the breeding phase of a beef-cattle production system (Barcelos et al., 1996). In this type of assessment, the system must be analyzed as a whole; possible adjustments for error prevention may yield contradictory results that may be misinterpreted, penalizing or overvaluing determined management techniques. As early weaning is a method used to make cows convert ingested nutrients into weight gain, as well as body condition and reproductive performance improvement, pregnancy rate is essential when evaluating production systems. When evaluating experimental results to assess the productivity and efficiency of breeds and breeding cattle production systems, caution must be taken when interpreting results, and the applied methodology must be considered (Barcellos et al., 1996).

When cow efficiency was evaluated (Table 3 ), it was found that those submitted to conventional weaning produced more calf kilogram for each $100 \mathrm{~kg}$ of cow metabolic weight relative to those submitted to early weaning (149.1 and $126.6 \mathrm{~kg}$, respectively). This is partially due to the longer period of nursing, allowing better development of calves as they remained longer with their dams (Restle et al., 1999; Vaz \& Lobato 2010a); however, cows gained less weight because of nursing for a longer period of time (Restle et al., 2001; Vaz \& Lobato, 2010b).

Ribeiro et al. (2001), worked with breeding cows under different feeding systems on cultivated pastures and verified that those maintained on better feeding conditions produced more calf weight per $100 \mathrm{~kg}$ of cow weight. Those authors also reported, in terms of efficiency at weaning, average values of $165 \mathrm{~kg}$ weaned calf per $100 \mathrm{~kg}$ cow metabolic weight. These values are higher than the $138.4 \mathrm{~kg}$ obtained in the present study, but the aforementioned authors weaned calves at 182 days of age. Restle et al. (2007), working with lactating cows, also observed that higher nutritional level is the factor that determines better biological results at the time of weaning, and asserted that calf performance is essential for the biological efficiency of beef cattle, which is consistent with the conclusions of Ribeiro et al. (2001).

The most significant benefit of early weaning is the raise on cow pregnancy rate (Moojen et al., 1994; Pascoal \& Vaz, 1997;
Restleetal.,2001; Fagundes etal.,2003; Almeida\&Lobato,2004). However, calf development during the time period between the two weaning ages is compromised, but it can be later compensated by an adequate feeding supply (Restle et al., 1999; Almeida \& Lobato, 2004; Lobato et al., 2007).

Therefore, production systems, whose aim is to sell weanlings, are compromised by early weaning, as the biological efficiency of cows is reduced. When calf weight was adjusted to pregnancy rate, the results were inverted, with 109.5 and $99.2 \mathrm{~kg}$ calf per kg cow metabolic weight for cows submitted to early and conventional weaning, respectively.

However, when results relative to calf production rates are analyzed (Table 3 ), it is observed that cows submitted to early weaning produced $73.9 \%$ more kilogram calf in the following breeding season as compared to those in the conventional weaning group. The results of 102.3 and $59.1 \mathrm{~kg}$ calf for the cows in the early weaning and conventional weaning groups, respectively, mean that early weaning is an efficient tool for the production of calf kilogram in the breeding season/weaning per cow maintained in the herd. Nevertheless, high birth rates are not always equal to higher production of $\mathrm{kg}$ calf per hectare. Beretta et al. (2001) worked with 82.5 and $92.5 \%$ birth rates, and obtained 83.9 and $77.9 \mathrm{~kg} / \mathrm{ha}$ calf production, respectively.

The results of the present study demonstrate that $73.9 \%$ more cows are required in the herd to produce the same amount of calf kilogram in the subsequent year in a herd submitted to conventional weaning. Better productivity indexes are obtained in systems with high reproductive rates and with heifers at low ages at first breeding and at slaughter of steers (Pötter et al., 2000; Beretta et al., 2002).

The better calf productivity and production efficiency of cows submitted to early weaning in the present experiment (Table 3 ) results from the higher number of cows exposed to mating during the breeding season, and not to pregnancy rate. On the other hand, the low pregnancy rate in the subsequent year of cows submitted to conventional weaning caused a higher culling rate, thereby reducing the number of cows exposed to mating during the subsequent season. The economic return of breeding herds requires cows to produce one calf per year and culling the open cows (Vaz et al., 2000).

In the present study, $92.7 \mathrm{vs} 58.6 \mathrm{~kg}$ calf/bred cow and 27.9 and $16.5 \mathrm{~kg}$ calf/cow at weaning per $100 \mathrm{~kg}$ cow in the early weaning and conventional weaning systems, respectively, were obtained. However, these values are lower than those of Euclides Filho et al. (1995), who worked with larger cows derived from Nelore $\times$ Chianina, Charolais and Fleckvieh crossbreedings. Ribeiro et al. (2001) worked 
with Abeerden Angus cows and crossbred calves, and showed that smaller and lighter cows presented better production efficiency, when calf weight was adjusted to 205 days.

Barcellos et al. (1996) obtained an average productivity of $117.9 \mathrm{~kg}$ ( $\mathrm{kg}$ calf $/ \mathrm{cow})$, and $29.4 \mathrm{~kg}$ ( $\mathrm{kg}$ calf $/ 100 \mathrm{~kg}$ cow) efficiency when working with primiparous cows of the following genotypes: $1 / 2$ Nelore $1 / 2$ Hereford, $1 / 4$ Nelore $3 / 4$ Hereford, and purebred Hereford. These results are similar to those obtained by Vieira et al. (2005) in Nelore herds in central Brazil. It must be noted that primiparous cows have lower body weight than multiparous cows, which may affect efficiency results, although primiparous cows tend to produce lighter calves at weaning.

\section{Conclusions}

Cows whose calves are weaned at 76 days of age present higher pregnancy, birth, and weaning rates as compared to cows whose calves are weaned at 148 days. Calf weight gain from birth to weaning is higher when they are weaned at 148 days of age, but these calves produce less calf weight per kilogram cow until weaning. Early weaning produces more calves (in $\mathrm{kg}$ live weight). The higher pregnancy and weaning rates of cows in the early weaning system determine higher production of $\mathrm{kg}$ calf $/ \mathrm{kg}$ cow maintained in the herd, higher productivity, and higher efficiency in $\mathrm{kg}$ weaned calf per cow mated in the previous breeding season.

\section{References}

ALMEIDA, L.S.P.; LOBATO, J.F.P.; Efeito da idade de desmame e suplementação no desenvolvimento de novilhas de corte. Revista Brasileira de Zootecnia, v.33, n.6 p.2086-2094, 2004 (supl.2).

ALMEIDA, L.S.P.; LOBATO, J.F.P.; SCHENKEL, F.S Data de desmame e desempenho reprodutivo de vacas de corte. Revista Brasileira de Zootecnia, v.31, n.3, p.1223-1229, 2002.

BARCELLOS, J.O.J.; LOBATO, J.F.P.; FRIES, L.A. Eficiência de vacas primíparas Hereford e cruzas Hereford-Nelore acasaladas no outono/inverno ou na primavera/verão. Revista Brasileira de Zootecnia, v.25, n.3, p.414-427, 1996.

BERETTA, V.; LOBATO, J.F.P.; MIELITZ NETO, C.G.A. Produtividade e eficiência biológica de sistemas pecuários de cria diferindo na idade das novilhas ao primeiro parto e na taxa de natalidade do rebanho no Rio Grande do Sul. Revista Brasileira de Zootecnia, v.30, n.4, p.1278-1286, 2001

BERETTA, V.; LOBATO, J.F.P.; MIELITZ NETO, C.G.A. Produtividade e eficiência biológica de sistemas de produção de gado de corte de ciclo completo no Rio Grande do Sul. Revista Brasileira de Zootecnia, v.31, n.2, p.991-1001, 2002 (supl.).

CORREAA, E.S.; ANDRADE, P.; EUCLIDES FILHO, K. et al. Avaliação de um sistema de produção de gado de corte. 1. Desempenho reprodutivo. Revista Brasileira de Zootecnia v.29, n.6, p.2209-2215, 2000 (supl.2).
COSTA, A.M.; RESTLE, J.; MÜLLER, L. Influência da pastagem cultivada no desempenho reprodutivo de vacas com cria ao pé Revista do Centro de Ciências Rurais, v.11, n.4, p.187-200, 1981.

EMPRESA BRASILEIRA DE PESQUISA AGROPECUÁRIA EMBRAPA. Sistema brasileiro de classificação de solos. Brasília: Embrapa Cerrados; Rio de Janeiro: Centro Nacional de Pesquisa de Solos, 1999. 412p.

EUCLIDES FILHO, K.; RESTLE, J.; OLSON, T.A. et al. Medidas de eficiência na produção de terneiros a partir de vacas de tamanho e habilidade leiteira diferentes. In: REUNIÃO ANUAL DA SOCIEDADE BRASILEIRA DE ZOOTECNIA, 21., 1984, Belo Horizonte. Anais... Belo Horizonte: SBZ, 1984. p.138.

EUCLIDES FILHO, K.; FIGUEIREDO, G.R.; EUCLIDES, V.P.B Eficiência de produção de vacas de corte com diferentes potenciais para a produção de leite. Pesquisa Agropecuária Brasileira, v.30, n.7, p.1003-1007, 1995.

FAGUNDES, J.I.B.; LOBATO, J.F.P.; SCHENKEL, F.S. Efeito de duas cargas animais em campo nativo e de duas idades a desmama no desempenho de vacas de corte primíparas. Revista Brasileira de Zootecnia, v.32, n.6, p.1722-1731, 2003 (supl.1).

FREETLY, H.C. The replacement heifer and the primiparous cow In: REUNIÃO ANUAL DA SOCIEDADE BRASILEIRA DE ZOOTECNIA, 36., 1999, Porto Alegre. Anais... Porto Alegre: SBZ, 1999. p.241-249.

LOBATO, J.F.P. A "vaca ideal" e seu manejo em sistemas de produção de ciclo curto. In: I SIMPÓSIO DA CARNE BOVINA - Da Produção ao consumidor. 2003, São Borja. Anais... 2003. Ed UFRGS. 2003 p.9-46.

LOBATO, J.F.P.; BARCELLOS, J.O.J. Efeito da utilização de pastagem melhorada no pós-parto e do desmame aos 100 ou 180 dias de idade no desempenho reprodutivo de vacas de corte Revista da Sociedade Brasileira de Zootecnia, v.21, n.3, p.385-395, 1992 .

LOBATO, J.F.P.; DERESZ, F.; LeBOUTE, E.M. et al. Pastagens melhoradas e suplementação alimentar no comportamento reprodutivo de vacas de corte primíparas. Revista Brasileira de Zootecnia, v.27, n.1, p.47-53, 1998a.

LOBATO, J.F.P.; ZANOTTA JR., R.L.D.; PEREIRA NETO, O.A Efeitos das dietas pré e pós-parto na eficiência reprodutiva de vacas primíparas de corte. Revista Brasileira de Zootecnia, v. 27, n.5, p.857-862, 1998b.

LOBATO, J.F.P.; MÜLLER, A.; PEREIRA NETO, O.A. et al. Efeitos da idade à desmama sobre o desempenho reprodutivo de vacas de corte primíparas. Revista Brasileira de Zootecnia v.29, n.6, p.2013-2018, 2000 (supl.1).

LOBATO, J.F.P.; ALMEIDA, L.S.P.; OSÓRIO, E.B. et al. Efeito da idade de desmame no desenvolvimento e nas características de carcaça de novilhos de corte. Revista da Sociedade Brasileira de Zootecnia, v.36, n.3, p.596-602, 2007.

MOOJEN, J.G., RESTLE, J., MOOJEN, E.L. Efeito da época de desmama e da pastagem no desempenho de vacas e terneiros de corte. 1. Desempenho das vacas. Ciência Rural, v.24, n.2, p.393-397, 1994.

MOREnO, J.A. Clima do Rio Grande do Sul. Porto Alegre: Secretaria da Agricultura. 1961. 41p.

PASCOAL, L.L.; VAZ, F.N. Desmame precoce aos sessenta dias. In: RESTLE, J. (Ed.) Técnicas avançadas na recria e engorda de bovinos de corte. Santa Maria: 1997. p.36-50.

PÖTTER, B.A.A.; LOBATO, J.F.P. Efeitos de carga animal, pastagem melhorada e da idade de desmame no comportamento reprodutivo de vacas primíparas. Revista Brasileira de Zootecnia, v.33, n.1, p.192-202, 2004

PÖTTER, B.A.A.; LOBATO, J.F.P.; SCHENKEL, F.S. Efeitos do manejo pós-parto de vacas primíparas no desempenho de bezerros de corte até um ano de idade. Revista Brasileira de Zootecnia, v.33, n.2, p.426-433, 2004.

PÖTTER, L.; LOBATO, J.F.P.; MIELITZ NETO, C.G.A. Análises econômicas de modelos de produção com novilhas de corte 
primíparas aos dois, três ou quatro anos de idade. Revista Brasileira de Zootecnia, v.29, n.3, p.861-870, 2000.

RESTLE, J.; HARGROVE, D. D.; KOGER, M. Cow performance in upgrading and rotational crossbreeding systems. Journal of Animal Science, v.59, n.1, p.45-46, 1984.

RESTlE, J.; POLli, V.A.; AlVES FILHO, D.C. et al. Desenvolvimento de bovinos de corte de diferentes grupos genéticos desmamados aos 3 ou 7 meses de idade. Revista Brasileira de Zootecnia, v.28, n.5, p.1023-1030, 1999.

RESTLE, J.; VAZ, R.Z.; ALVES FILHO, D.C. et al. Desempenho de vacas Charolês e Nelore desterneiradas aos três ou sete meses. Revista Brasileira de Zootecnia, v.30, n.2, p.499-507, 2001.

RESTLE, J.; PACHECO, P.S.; FREITAS, A.K. et al. Influência das taxas de ganho de peso pré-desmame das vacas e do tipo de pastagem no período pós-parto sobre a eficiência biológica de vacas e de bezerros de corte. Revista Brasileira de Zootecnia, v.36, n.4, p.874-880, 2007.

RIBEIRO, E.L.A.; RESTLE, J.; ROCHA, M.A. et al. Eficiência produtiva em vacas primíparas das raças Aberdeen Angus e Charolês. Revista Brasileira de Zootecnia, v.30, n.1, p.125-132, 2001.

ROVIRA, J.M. Reproducción y manejo de los rodeos de cria. Montivideo: Hemisfério Sur, 1974. 293p.

SIMEONE, A.; LOBATO, J.F.P. Efeitos da lotação animal em campo nativo e do controle da amamentação no comportamento reprodutivo de vacas de corte primíparas.
Revista Brasileira de Zootecnia, v.25, n.6, p.1216-1227, 1996.

SHORT, R.E.; BELLOWS, R.A.; STAIGMILLER, R.B. et al Physiological mechanisms controlling anestrus and infertility in post partum beef cattle. Journal of Animal Science, v.68, n.3, p.799-816, 1990 .

STATISTICAL ANALYSIS SYSTEM - SAS. SAS/STAT user's guide: statistics. 4.ed. Version 6. Cary: 1997. v.2, 943 p.

VAZ, F.N.; ROSO, C.; VAZ, R.Z. Aplicação gerenciamento de tecnologias na pecuária de corte moderna In: RESTLE, J. (Ed.) Eficiência na produção de bovinos de corte. Santa Maria: 2000. p.333-368.

VAZ, R.Z.; LOBATO, J.F.P. Efeito da idade de desmame no desenvolvimento de novilhas de corte até os 14/15 meses de idade. Revista Brasileira de Zootecnia, v.39, n.2, p.289-298, 2010a.

VAZ, R.Z.; LOBATO, J.F.P. Efeitos da idade ao desmame no desenvolvimento somático e desempenho reprodutivo de vacas de corte. Revista Brasileira de Zootecnia, v.39, n.5, p.1058-1067,2010b.

VIEIRA, A.; LOBATO, J.F.P.; CORREA, E.S. et al. Produtividade e eficiência de vacas Nelore em pastagem de Brachiaria decumbens Stapf nos cerrados do Brasil Central. Revista Brasileira de Zootecnia, v.34, n.4, p.1357-1365, 2005. 